\title{
Correction to: Genetic structure of selected finfish populations in the Galapagos Islands, Ecuador
}

\author{
Zohrah Sulaiman $^{1,2} \cdot$ Mei Ann Lim² $\cdot$ Hussein Taha ${ }^{2}$
}

Published online: 3 June 2021

(c) Senckenberg Gesellschaft für Naturforschung 2021

\section{Erratum to: Marine Biodiversity (2021) 51:41 https://doi.org/10.1007/s12526-021-01179-8}

The online version of this article contained a number of typesetting errors which the editor wished to rectify, but it was inadvertently sent for publication before the required corrections were implemented. The publisher would like to apologize for this mistake.

The original article has been corrected.

Publisher's Note Springer Nature remains neutral with regard to jurisdictional claims in published maps and institutional affiliations.

The original article can be found online at https://doi.org/10.1007/ s12526-021-01179-8.

Zohrah Sulaiman

zohrah.sulaiman@utb.edu.bn

1 Universiti Teknologi Brunei, Tungku Link Road, Gadong, Bandar Seri Begawan BE1410, Brunei Darussalam

2 Universiti Brunei Darussalam, Tungku Link Road, Gadong, Bandar Seri Begawan BE1410, Brunei Darussalam 